\title{
Protogrammus alboranensis n. sp. (Teleostei: Callionymidae), a new species of dragonet from the Alboran Sea, western Mediterranean Sea
}

\author{
Carlos Farias ${ }^{1}$, Francesc Ordines ${ }^{2}$, Cristina García-Ruiz ${ }^{3}$, Ronald Fricke ${ }^{4,5}$ \\ ${ }^{1}$ Instituto Español de Oceanografía, Centro Oceanográfico de Cádiz. Muelle de Levante (Puerto Pesquero), \\ 11006 Cádiz, Spain. \\ ${ }^{2}$ Instituto Español de Oceanografía, Centre Oceanogràfic de les Balears, Moll de Ponent s/n, 07015 Palma de Mallorca, \\ Spain. E-mail: xisco.ordinas@ba.ieo.es \\ ${ }^{3}$ Instituto Español de Oceanografía, Centro Oceanográfico de Málaga. Puerto Pesquero s/n, 29620 Fuengirola, \\ Málaga, Spain. \\ ${ }^{4}$ Im Ramstal 76, 97922 Lauda-Königshofen, Germany. E-mail: ronfricke@web.de \\ ${ }^{5}$ Staatliches Museum für Naturkunde Stuttgart, Rosenstein 1, 70191 Stuttgart, Germany.
}

Summary: Protogrammus alboranensis n. sp. is described on the basis of four specimens from the Alboran Sea, western Mediterranean Sea. It is characterized within the genus Protogrammus by a total of nine unbranched rays on the second dorsal fin, eight unbranched rays on the anal fin, a very small preopercular spine with an upcurved main tip and one point on the dorsal margin, which is lacking an antrorse spine at the base, the first and second spines of the first dorsal fin filamentous and much longer than the first ray of the second dorsal fin in males, the tip of the last ray of the second dorsal fin reaching beyond the caudal fin base in males, and the anal fin distally black in the males (translucent in females). A key to the species of Protogrammus is presented; the zoogeography of the species is discussed.

Keywords: new species; Callionymidae; Protogrammus; beam trawl; Alboran platform; western Mediterranean.

Protogrammus alboranensis n. sp. (Teleostei: Callionymidae), una nueva especie de dragón del mar de Alborán, mar Mediterráneo occidental

Resumen: En base a cuatro individuos recolectados en el mar de Alborán, mar Mediterráneo occidental, se describe Protogrammus alboranensis $\mathrm{n}$. sp. Esta especie se caracteriza dentro del género Protogrammus por poseer un total de 9 radios no ramificados en la segunda aleta dorsal, 8 radios no ramificados en la aleta anal, una espina preopercular muy pequeña que carece de espina antrorsa en la base y que posee una punta principal curvada hacia arriba y otra en el margen dorsal, la primera y segunda espinas de la primera aleta dorsal son filamentosas y mucho más largas que el primer radio de la segunda aleta dorsal en el macho, la punta del último radio de la segunda aleta dorsal alcanza más allá de la base de la aleta caudal en el macho, y la aleta anal presenta un margen oscuro en machos (traslúcido en hembras). Se presenta una clave para las especies del género Protogrammus y se discute sobre su zoogeografía.

Palabras clave: nueva especie; Callionymidae; Protogrammus; patín epibentónico; plataforma de Alborán; Mediterráneo occidental.

Citation/Como citar este artículo: Farias C., Ordines F., García-Ruiz C., Fricke R. 2016. Protogrammus alboranensis n. sp. (Teleostei: Callionymidae), a new species of dragonet from the Alboran Sea, western Mediterranean Sea. Sci. Mar. 80(1): 51-56. doi: http://dx.doi.org/10.3989/scimar.04340.13A

LSID: urn:1sid:zoobank.org:pub:95082E07-55EB-4350-927A-1718CD491609

Editor: G. Pequeño.

Received: August 27, 2015. Accepted: November 3, 2015. Published: January 20, 2016.

Copyright: (c) 2016 CSIC. This is an open-access article distributed under the Creative Commons Attribution-Non Commercial Lisence (by-nc) Spain 3.0. 


\section{INTRODUCTION}

Dragonets are benthic fishes of the family Callionymidae. They occur from the surface to $900 \mathrm{~m}$ depth. Callionymid fish species are present in all temperate, subtropical and tropical oceans of the world. Fricke (2002) summarized the knowledge about the family Callionymidae in a checklist; he dealt with 182 valid, recent species in 10 genera. Since then, the account has only increased by 10 new species and a new genus (Fricke 2006, Motomura and Mukai 2006, Ng and Rainboth 2011, Allen and Erdmann 2012, Fricke and Golani 2013, Fricke 2014, Fricke et al. 2014a, b), plus one more that was removed from synonymy (Yoshigou et al. 2006), adding to a total of 193 valid species in 11 genera.

From the Mediterranean Sea, only two callionymid fish genera have been reported: Synchiropus, represented by Synchiropus phaeton (Günther, 1861) and the Lessepsian migrant S. sechellensis Regan, 1908; and Callionymus, represented by Callionymus fasciatus Valenciennes, 1837; Callionymus filamentosus Valenciennes, 1837 (a Lessepsian migrant); Callionymus lyra Linnaeus, 1758; Callionymus maculatus Rafinesque, 1810; Callionymus pusillus Delaroche, 1809; Callionymus reticulatus Valenciennes, 1837; and Callionymus risso Lesueur, 1814 (Fricke 1986a, Gökoğlu et al. 2014). Except for S. sechellensis, recorded in the Mediterranean for the first time in 2014, the number of species in this area has not increased since 1986 (Fricke 1986a).

The genus Protogrammus was first described by Fricke (1985), based on P. sousai (Maul, 1972), from Great Meteor Seamount west of Madeira in the northeastern Atlantic. A second species, P. antipodus, was described by Fricke (2006) from Lifou, Loyalty Islands, southwestern Pacific. Both species are very rare, known only from a few specimens each, and live on sand bottoms on seamounts or lower island shelves and slopes. This disjunctive distribution is very unusual; it was considered as a relict distribution by Fricke (2006).
The related genera Diplogrammus (Indo-West Pacific) and Chalinops (western Atlantic) are more common, more widespread, and replace species of Protogrammus in shallow water.

In the present work, a previously undescribed species of Protogrammus is reported from the Alboran platform, western Mediterranean, based on four specimens collected with a beam trawl.

\section{MATERIALS AND METHODS}

In the framework of the IRIS-SES project, during the MEDITS bottom trawl survey of 2014 in the Alboran Sea, 23 beam trawl samples were taken (steel frame, $10 \mathrm{~mm}$ mesh in the codend, $1.3 \mathrm{~m}$ horizontal opening). In one of those samples carried out on the Alboran platform, near Alboran Island, at $113 \mathrm{~m}$ depth (Fig. 1), two male specimens of the new Protogrammus species were collected. In 2015, and again during the MEDITS survey, 14 beam trawl samples were taken, and two more samples were carried out at the same sampling station from the Alboran platform where the new Protogrammus species had been caught in 2014. This time seven specimens of the new species were collected: one female in one sample and one male and five females in the other.

The description of the specimens, including classification, methodology and fin ray counts follow Fricke (1983a, b, 1985, 2002). Museum acronyms follow Fricke and Eschmeyer (2015). Counts of the paratypes follow those of the holotype, in parentheses.

Comparative material: Protogrammus antipodus: SMNS 23698 (holotype), Lifou, Loyalty Islands, New Caledonia, 200-220 m depth; MNHN 2006-1235 (1 paratype), Lifou, Loyalty Islands, New Caledonia, 70-130 m depth. Protogrammus sousai: MMF 22877 (holotype), Great Meteor Seamount, 315-320 m depth; MMF 22389 (1 paratype), Great Meteor Seamount, 310 m depth; MMF 22843a (1 paratype), Great Meteor Seamount; MMF 22843b (1 paratype), Great Meteor Seamount.
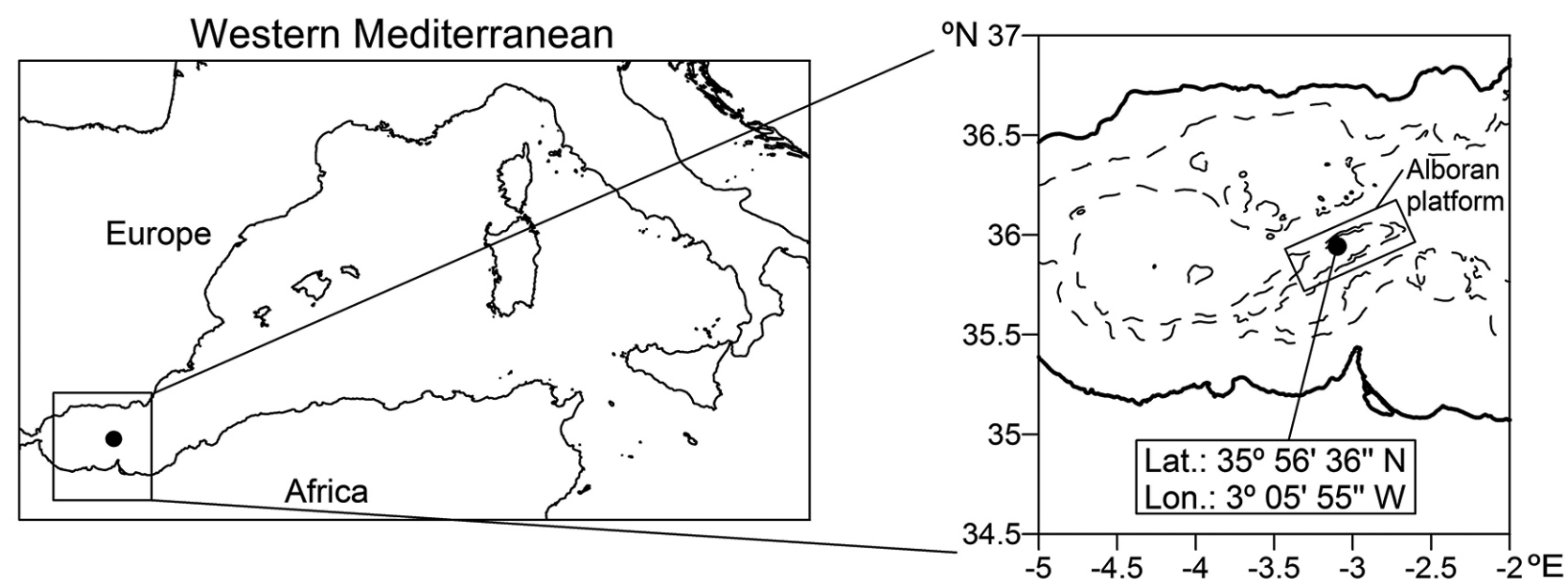

Fig. 1. - Map of the area indicating (with a black dot) the locality of the beam trawls in which the Protogrammus alboranensis n. sp. was caught. Isobaths correspond to 600 and $1000 \mathrm{~m}$ depth. Alboran Island, more or less in the centre of the Alboran platform, is so small that it barely appears at the scale of the map. 


\section{TAXONOMY}

Protogrammus alboranensis Fricke, Ordines, Farias and García-Ruiz (Figs 2 and 3)

Holotype: CFM_IEOMA 5557, male, $50.2 \mathrm{~mm}$ standard length

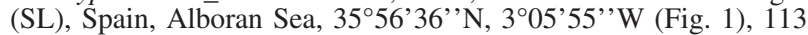
$m$ depth, Instituto Español de Oceanografía, survey MEDITS ES_1405, haul 15, beam trawl, 1 May 2014.

Paratypes: CFM_IEOMA 5558, male, $48.1 \mathrm{~mm} \mathrm{SL}$, collected in the same sample as the holotype. SMF 35715, male (no. 6), $36.5 \mathrm{~mm}$ SL, Spain, Alboran Sea, 35 56'19',N, $3^{\circ} 05^{\prime} 48^{\prime}$ 'W, $113 \mathrm{~m}$ depth, Instituto Español de Oceanografía, survey MEDITS_ES_1505, haul 11, beam trawl, 30 April 2015. SMF 35716, female $24.5 \mathrm{~mm} \mathrm{SL}$, collected in the same sample as the paratype SMF 35715.

Diagnosis. A species of Protogrammus with a total of nine unbranched rays on the second dorsal fin, eight unbranched rays on the anal fin, a very small preopercular spine with an upcurved main tip and one point on the dorsal margin, which is lacking an antrorse spine at the base, the first and second spines of the first dorsal fin filamentous and much longer than the first ray of the second dorsal fin in males, the tip of last ray of the second dorsal fin reaching beyond the caudal fin base in males, and the anal fin distally black in males.

Description. Fin-ray counts: D IV (IV) + viii, 1 (viii,1); A vii,1 (vii,1); $\mathrm{P}_{1}$ ii,17,ii (ii, 16-18,ii) (total 20-22); P I,5 (I,5); C (i),i,7,ii,(i) [( i),i,7,ii,( i)]. Morphometric measurements and proportions are given in Table 1.

Body elongated and depressed. Head depressed. Branchial opening dorsal in position. Preopercular spine very small; preopercular spine formula, with a single point on its dorsal margin similar in size to the main tip,
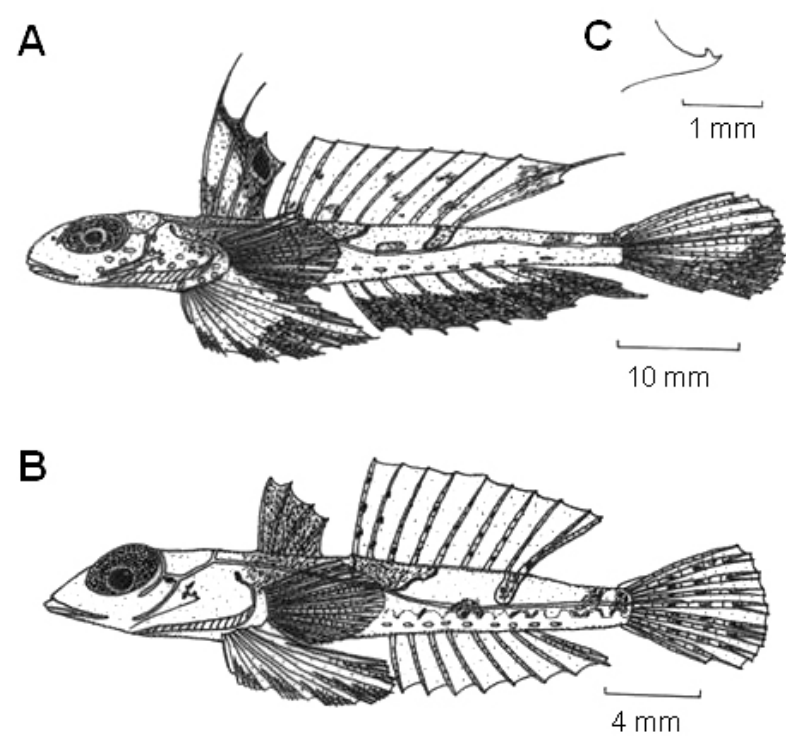

Fig. 2. - Lateral view of Protogrammus alboranensis n. sp. with reconstructed membranes and coloration of vertical fins according to the preserved specimens: A) CFM_IEOMA 5558, male, $60.8 \mathrm{~mm}$ total length, paratype; B) SMF 35716 , female, $30.3 \mathrm{~mm}$ total length, paratype. C) Left preopercular spine.

both curved and pointing upwards; ventral margin and base smooth, without points (Fig. 3). Lower half of operculum with a free flap of skin, but upper half connected with the body. Urogenital papilla elongate. Lateral line reaching from preorbital region to end of fourth branched caudal fin ray (counted from above), upcurved below end of first dorsal fin base and beginning of second dorsal fin base, then slightly downcurved, again upcurved above end of anal fin base, with a number of short dorsal
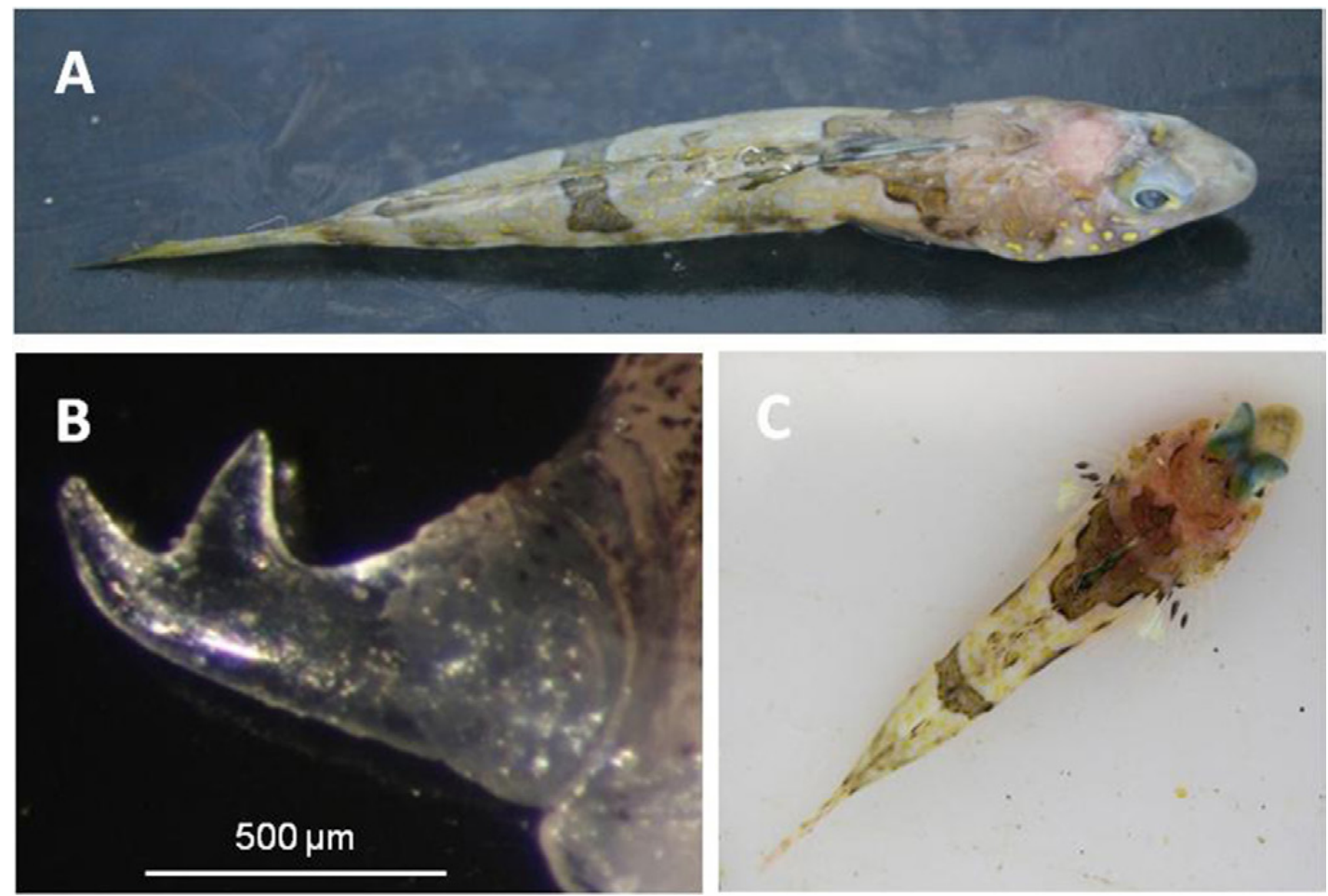

Fig. 3. - Photographs of Protogrammus alboranensis n. sp.: A) holotype CFM_IEOMA 5557, male, 63.8 mm total length; B) dorsal view and detail of the right preopercular spine of the holotype; and C) paratype SMF 35716, female, $30.3 \mathrm{~mm}$ total length, alive. 
Table 1. - Morphometric measurements and proportions of the holotype and paratypes of Protogrammus alboranensis n. sp. SL, standard length; HL, head length.

\begin{tabular}{|c|c|c|c|c|c|c|c|c|}
\hline \multirow{2}{*}{ Morphometric measurements } & \multicolumn{2}{|c|}{$\begin{array}{c}\text { Holotype } \\
\text { (CFM_IEOMA 5557, male) }\end{array}$} & \multicolumn{2}{|c|}{$\begin{array}{c}\text { Paratype } \\
\text { (CFM_IEOMA 5558, male) }\end{array}$} & \multicolumn{2}{|c|}{$\begin{array}{c}\text { Paratype } \\
\text { (SMF 35715, male) }\end{array}$} & \multicolumn{2}{|c|}{$\begin{array}{c}\text { Paratype } \\
\text { (SMF 35716, female) }\end{array}$} \\
\hline & $\mathrm{mm}$ & Proportion & $\mathrm{mm}$ & Proportion & $\mathrm{mm}$ & Proportion & $\mathrm{mm}$ & Proportion \\
\hline Standard Length (SL) & 50.2 & & 48.1 & & 36.5 & & 24.5 & \\
\hline Total Length & 63.8 & & 60.8 & & 45.9 & & 30.3 & \\
\hline Body width & 7.2 & 7.0 in SL & 7.0 & 6.9 in SL & 6.4 & 5.7 in SL & 5.1 & 4.8 in SL \\
\hline Body depth & 6.2 & 8.1 in SL & 5.1 & 4.0 in SL & 5.3 & 6.9 in SL & 4.0 & 6.1 in SL \\
\hline Caudal peduncle length & 7.4 & 6.8 in SL & 10.6 & 4.5 in SL & 8.4 & 4.3 in SL & 4.5 & 5.4 in SL \\
\hline Caudal peduncle depth & 2.2 & 22.7 in SL & 2.2 & 21.9 in SL & 1.8 & 20.3 in SL & 1.6 & 15.3 in $\mathrm{SL}$ \\
\hline Predorsal (1) length & 14.4 & 3.5 in SL & 13.8 & 3.5 in SL & 12.1 & 3.0 in SL & 9.0 & 2.7 in SL \\
\hline Predorsal (2) length & 21.2 & 2.4 in SL & 20.2 & 2.4 in SL & 18.6 & 2.0 in SL & 12.8 & 1.9 in SL \\
\hline Head Length (HL) & 13.9 & 3.6 in SL & 11.3 & 4.3 in SL & 11.2 & 3.2 in SL & 8.3 & 3.0 in SL \\
\hline Eye diameter & 4.6 & 3.0 in $\mathrm{HL}$ & 4.4 & 2.6 in $\mathrm{HL}$ & 3.8 & 2.9 in $\mathrm{HL}$ & 3.1 & 2.7 in $\mathrm{HL}$ \\
\hline Preorbital length & 3.7 & 3.8 in $\mathrm{HL}$ & 3.2 & 3.5 in HL & 2.9 & 3.9 in $\mathrm{HL}$ & 1.6 & 5.2 in $\mathrm{HL}$ \\
\hline Upper jaw length & 4.7 & 2.9 in $\mathrm{HL}$ & 4.2 & 2.7 in $\mathrm{HL}$ & 3.6 & $3.1 \mathrm{in} \mathrm{HL}$ & 3.1 & 2.7 in HL \\
\hline Interorbital width & 0.7 & 19.8 in $\mathrm{HL}$ & 0.6 & 18.8 in HL & 0.9 & 12.4 in $\mathrm{HL}$ & 0.5 & 16.6 in $\mathrm{HL}$ \\
\hline 1st dorsal spine length & 13.2 & 3.8 in $\mathrm{SL}$ & 13.1 & 3.7 in SL & 8.6 & 4.2 in $\mathrm{SL}$ & 3.4 & 7.2 in SL \\
\hline 2nd dorsal spine length & 12.1 & 4.1 in SL & 11.5 & 4.2 in SL & 8.3 & 4.4 in SL & 3.1 & 7.9 in SL \\
\hline 3rd dorsal spine length & 11.4 & 4.4 in SL & 6.8 & 7.1 in SL & 6.3 & 5.8 in SL & 2.3 & 10.6 in $\mathrm{SL}$ \\
\hline 4th dorsal spine length & 11.0 & 4.6 in SL & 5.8 & 8.3 in SL & 5.1 & 7.2 in SL & 1.9 & 12.9 n SL \\
\hline 1st dorsal ray length & 7.8 & 6.4 in SL & 6.8 & 7.1 in SL & 6.4 & 5.7 in SL & 4.3 & 5.7 in SL \\
\hline Last dorsal ray length & 13.4 & 3.7 in SL & 14.6 & 3.3 in SL & 9.2 & 4.0 in SL & 3.9 & 6.3 in SL \\
\hline 1 st anal ray length & 4.8 & 10.4 in SL & 4.7 & 10.2 in $\mathrm{SL}$ & 3.9 & 9.4 in SL & 2.3 & $10.6 \mathrm{n} \mathrm{SL}$ \\
\hline Last anal ray length & 10.8 & 4.6 in SL & 11.9 & 4.0 in SL & 7.2 & 5.1 in SL & 3.7 & 6.6 in SL \\
\hline Pectoral fin length & 11.0 & 4.6 in SL & 8.5 & 5.7 in SL & 7.5 & 4.9 in SL & 4.9 & $5.0 \mathrm{n} \mathrm{SL}$ \\
\hline Pelvic spine length & 3.1 & 16.2 in SL & 2.8 & 17.2 in SL & 3.2 & 11.4 in SL & 1.7 & 14.4 in SL \\
\hline Pelvic fin length & 15.7 & 3.2 in $\mathrm{SL}$ & 14.8 & 3.2 in $\mathrm{SL}$ & 12.2 & 3.0 in SL & 7.3 & 3.4 in SL \\
\hline Preopercular spine length & 0.7 & 15.4 in $\mathrm{HL}$ & 1.3 & 8.7 in $\mathrm{HL}$ & 0.8 & 14.0 in $\mathrm{HL}$ & 0.7 & 11.9 in HL \\
\hline Urogenital papilla length & 1.3 & 10.7 in $\mathrm{HL}$ & 1.1 & 10.3 in $\mathrm{HL}$ & 0.8 & 14.0 in $\mathrm{HL}$ & -- & -- \\
\hline D1 base length & 6.2 & 8.1 in $\mathrm{SL}$ & 4.6 & 10.5in SL & 4.8 & 7.6 in SL & 2.5 & 9.8 in SL \\
\hline D2 base length & 14.8 & 3.4 in SL & 14.0 & 3.4 in SL & 10.1 & 3.6 in SL & 8.5 & 2.9 in SL \\
\hline Caudal fin length & 13.6 & 3.7 in SL & 13.2 & 3.6 in SL & 9.4 & 3.9 in SL & 5.8 & 4.2 in SL \\
\hline Preanal length & 24.9 & 2.0 in SL & 25.6 & 1.9 in SL & 19.7 & 1.9 in SL & 14.4 & 1.7 in SL \\
\hline Anal fin base length & 12.8 & 3.9 in SL & 13.1 & 3.7 in SL & 7.9 & 4.6 in SL & 5.6 & 4.4 in SL \\
\hline Prepectoral length & 16.8 & 3.0 in SL & 15.6 & 3.1 in SL & 13.8 & 2.6 in SL & 9.6 & 2.6 in SL \\
\hline Pectoral fin base length & 3.8 & 13.2 in SL & 3.3 & 14.6 in SL & 2.7 & 13.5 in SL & 2.0 & 12.2 in SL \\
\hline Prepelvic length & 12.8 & 3.9 in SL & 12.3 & 3.9 in $\mathrm{SL}$ & 10.2 & 3.6 in SL & 7.2 & 3.4 in SL \\
\hline Pelvic fin base length & 3.2 & 15.6 in SL & 3.8 & 12.7 in $\mathrm{SL}$ & 1.7 & 21.5 in SL & 1.2 & 20.4 in SL \\
\hline
\end{tabular}

and ventral branches along the sides of the body, and with a long preopercular branch; lines of the opposite sides interconnected across the occipital region, but not across the dorsal part of the caudal peduncle. Sides of body between the lateral line and the anal fin base have a ventrolateral fold of skin consisting of 11 (9-11) short, disconnected segments not reaching the caudal peduncle, which are reduced and difficult to detect.

First and second spines of first dorsal fin in the male long, filamentous, much longer than first ray of second dorsal fin; in the female low, without filaments. Rays of second dorsal fin unbranched, the last divided at its base, the upper branch elongate and filamentous, reaching beyond the caudal fin base when laid back. Rays of anal fin unbranched, the last divided at its base, the lower branch elongate and filamentous, reaching beyond the caudal fin base when laid back. Pectoral fin reaching to the base of the first anal fin ray when laid back. Pelvic fin large, fourth ray elongate, reaching to base of third anal fin membrane when laid back. Caudal fin elongate, without filaments.

Colours in life are shown in Figure 3. Male: Head pale brownish grey with several golden spots on the cheeks, preoperculum and operculum. Occipital region rosy. The body is pale grey, with four dark brown dorsal patches, two of them (the one on the nape and the one coinciding with the first half of the second dorsal fin) darker than the rest, and a slender yellow reticule on the sides of the body. The first dorsal fin is distally dark, with a blackish blotch distally on the third membrane. The second dorsal fin has four thin, yellow horizontal lines. Anal fin is distally blackish. Lower one-third of caudal fin and lower distal margin are blackish; upper parts of caudal fin with golden bars and blotches. Pectoral fin pale; pelvic fin has a greyish area distally on third and fourth rays. Female: The head and body coloration is similar to the male, except that the female is lacking golden spots on the cheeks, preoperculum and operculum. The first dorsal fin is mottled with grey; the second dorsal fin bears irregular brown spots on the fin rays; the anal fin is translucent, without dark markings, the rays white. The pectoral fin is plain white; the pelvic fin is white with three dark blotches located near the base of the three inner rays; the caudal fin is translucent, with three vertical rows of spots on the fin rays.

Etymology. Its name is based on the type locality, the Alboran Sea, western Mediterranean.

Distribution and habitat. The species is only known from the type locality, Spain, Alboran Sea, Alboran platform $\left(35^{\circ} 56 \mathrm{~N}, 3^{\circ} 05 \mathrm{E}\right)$. The type series was collected in one sample at a depth of $113 \mathrm{~m}$ on a coarse sand bottom with many deep sea oyster shell remains (Neopycnodonte cochlear).

The most abundant fish species accompanying the new species were Arnoglossus thori Kyle, 1913, 
Callionymus maculatus Rafinesque, 1810, Diplecogaster bimaculata (Bonnaterre, 1788), Serranus cabrilla (Linnaeus, 1758), and Serranus hepatus (Linnaeus, 1758).

Comparisons. Protogrammus alboranensis n. sp. is characterized as a member of the genus Protogrammus by the very small preopercular spine, the lower lip lacking papillae, the presence of a free opercular flap of skin that is connected to the body only in its upper half, the presence of a ventrolateral fold of skin along the lower sides of the body which is much reduced and consisting of a few, short, disconnected segments, and unbranched rays in the second dorsal and anal fins (except for the last which is each divided at its base). From the western Atlantic species Chalinops pauciradiatus (Gill, 1865), which lives in sand and seagrass habitats of 2-27 $\mathrm{m}$ depth, the new species differs in the more numerous but unbranched second dorsal and anal rays (5-6 branched rays in second dorsal fin, 4 unbranched rays in anal fin in $C$. pauciradiatus), a single dorsal point on the preopecular spine ( 2 in $C$. pauciradiatus), the presence of a free opercular flap of skin (lacing in C. pauciradiatus), and the ventrolateral fold of skin which consists of small, disconnected, reduced, barely distinguishable segments (ventrolateral fold strong and continuous in $C$. pauciradiatus).

The new species is compared with the other species of the genus in the updated identification key (see below). It is similar to Protogrammus sousai, from the Great Meteor Bank, northeastern Atlantic, in its preopercular spine with a single dorsal point but without an antrorse basal point, but differs from that species in the upcurved main tip of the preopercular spine (straight in $P$. sousai); first and second spines of the first dorsal fin in males are much longer than first ray of second dorsal fin, bearing filaments (as long as first ray in $P$. sousai, and not filamentous); anal fin distally black in males (pale in P. sousai); tip of last ray of second dorsal fin reaching beyond caudal fin base in males (not reaching caudal fin base in $P$. sousai), and the body coloration with golden spots on the cheeks and brown saddles on the body (pale in $P$. sousai). Protogrammus alboranensis is distinguished from $P$. antipodus by its preopercular spine with only one dorsal point and no antrorse spine at its base (3-7 dorsal points and an antrorse spine at the base in $P$. antipodus), the wavy lateral line along the sides of the body (straight in $P$. antipodus), the total of 8 anal fin rays (total of 7 in $P$. antipodus), the ventrolateral fold of skin consisting of 11 short segments, not reaching the caudal peduncle (only 7, longer segments which are extending on the caudal peduncle in $P$. antipo$d u s$ ), and the distally black anal fin in the male (anal fin with a small distal dark blotch on each membrane only in male $P$. antipodus).

\section{Key to the species of the genus Protogrammus}

1- Preopercular spine with 3-7 dorsal points, and an antrorse spine at its base; anal fin with a total of 7 rays; southwestern Pacific
- Preopercular spine with 1 dorsal point, and no antrorse spine at its base; anal fin with a total of 8 rays; eastern Atlantic and western Mediterranean Sea.....

2- Main tip of preopercular spine straight; first and second spines of first dorsal fin in male nearly as long as first ray of second dorsal fin, without filaments; anal fin pale; tip of last ray of second dorsal fin not reaching caudal fin base in male; northeastern Atlantic Ocean. P. sousai

- Main tip of preopercular spine upcurved; first and second spines of first dorsal fin in male much longer than first ray of second dorsal fin, bearing filaments; anal fin distally black in males, translucent in females; tip of last ray of second dorsal fin reaching beyond caudal fin base in male; western Mediterranean Sea ......................... alboranensis

\section{DISCUSSION}

The new species of Protogrammus is an interesting finding of a third species of this rare genus, and the first record of this genus from the Mediterranean Sea. In the shape of the preopercular spine this species mostly resembles $P$. sousai from Great Meteor Seamount. The type locality of the new species on the shelf of the Alboran platform, near to Alboran Island in the western Mediterranean, is exposed to influx of Atlantic Ocean water through the Strait of Gibraltar.

The relict distribution of the genus Protogrammus, which is known only from the northeastern Atlantic, the western Mediterranean, and the southwestern Pacific, and the state of the ventrolateral fold of skin, which is more primitive than in the derived genera Diplogrammus and Chalinops, suggests that the ancestors of Protogrammus have been in the area for a long time, and appeared in the region before the closure of the Tethys Sea. During the Messinian salinity crisis in the late Miocene, Mediterranean species such as the ancestors of Protogrammus alboranensis were probably in exile in the eastern Atlantic; they immigrated into the Mediterranean again after it filled with Atlantic Ocean water (Fricke 1986b). The speciation event between Protogrammus sousai and P. alboranensis may have happened after this re-immigration, since the Strait of Gibraltar now forms a barrier to dispersal of Protogrammus larvae. Callionymid fish larvae, which are found in shallow water close to the surface only, can only disperse with the prevailing current from the eastern Atlantic to the Mediterranean, but usually not in the other direction against the current (Fricke 1986b). The deep countercurrent runs too deep to support the dispersal of larval Protogrammus. While it is likely that the ancestral Protogrammus formerly had a wider distribution in the eastern Atlantic, today's distribution range of Protogrammus sousai around seamounts west of Madeira is too far away from the Strait of Gibraltar to support the western Mediterranean with larval fish dispersal. This barrier prevents the exchange of larvae, so the evolution of separate species east and west of the barrier is enhanced. 


\section{ACKNOWLEDGEMENTS}

We would like to thank Desiree Palomino for supplying the bathymetric map. We are also grateful to Angel Mateo and Jose Luis Rueda for the photographs of the male and the live female, respectively. Thanks to Helena Gallardo and Alfonso Díaz (the benthos team) for their friendly help during the survey.

\section{REFERENCES}

Allen G.R., Erdmann M.V. 2012. A new species of dragonet (Synchiropus: Callionymidae) from Indonesia. Aqua, Int. J. Ichthyol. 18: 9-14.

Fricke R. 1983a. A method of counting caudal fin rays of actinopterygian fishes. Braunschweiger Naturkundliche Schriften 1: 729-733.

Fricke R. 1983b. Revision of the Indo-Pacific genera and species of the dragonet family Callionymidae (Teleostei). [Theses Zoologicae 3]. J. Cramer, Braunschweig, 774 pp.

Fricke R. 1985. Protogrammus, a new genus of callionymid fishes, with a redescription of $P$. sousai from the eastern Atlantic. Jap. J. Ichthyol. 32(3): 294-298.

Fricke R. 1986a. Callionymidae. In: Whitehead P.J.P., Bauchot M.L., et al. (eds) Fishes of the North-eastern Atlantic and the Mediterranean. UNESCO, París, pp. 1086-1093.

Fricke R. 1986b. Zoogeographie der Callionymidae (Osteichthyes: Perciformes) des Atlantischen Ozeans. Dipl. thesis, Technische Universität Braunschweig, 164 pp.

Fricke R. 2002. Annotated checklist of the dragonet families Callionymidae and Draconettidae (Teleostei: Callionymoidei), with comments on callionymid fish classification. Stuttgarter Beiträge zur Naturkunde, Serie A (Biologie) 645: 103 pp.

Fricke R. 2006. Two new species and a new record of dragonets from New Caledonia (Teleostei: Callionymidae). Stuttgarter
Beiträge zur Naturkunde, Serie A (Biologie) 696: 14 pp.

Fricke R. 2014. Callionymus madangensis, a new species of dragonet from Papua New Guinea, southwestern Pacific Ocean (Teleostei: Callionymidae). J. Ocean Sci. Found. 13: 1-15.

Fricke R., Eschmeyer W.N. 2015. Guide to fish collections in the Catalog of fishes. Internet publication, San Francisco (California Academy of Sciences). Online version, updated 5 March 2015. http://research.calacademy.org/research/Ichthyology/Catalog/ collections.asp

Fricke R., Golani D. 2013. Callionymus profundus n. sp., a new species of dragonet from the Gulf of Aqaba (Gulf of Eilat), Red Sea (Teleostei: Callionymidae). Stuttgarter Beiträge zur Naturkunde Serie A (Biologie), Neue Serie 6: 277-285.

Fricke R., Bogorodsky S.V., Mal A.O. 2014a. Review of the genus Diplogrammus (Teleostei: Callionymidae) of the Red Sea, with description of a new species from Saudi Arabia. J. Nat. Hist. 48: 2419-2448 http://dx.doi.org/10.1080/00222933.2014.925598

Fricke R., Jawad L.A., Al-Mamry J.M. 2014b. Callionymus omanensis, a new species of dragonet from Oman, north-western Indian Ocean (Teleostei: Callionymidae). J. Fish. Biol. 85: 1303-1319. http://dx.doi.org/10.1111/jfb.12460

Gökoğlu M., Özvarol Y., Fricke R. 2014. Synchiropus sechellensis Regan 1908 (Teleostei: Calionymidae), a new Lessepsian migrant in the Mediterranean Sea. Mediterr. Mar. Sci. 15(2): 440-442.

Motomura H., Mukai T. 2006. Tonlesapia tsukawakii, a new genus and species of freshwater dragonet (Perciformes: Callionymidae) from Lake Tonle Sap, Combodia. Ichthyol. Explor. Freshw. 17: 43-52.

Ng H.H., Rainboth W.J. 2011. Tonlesapia amnica, a new species of dragonet (Teleostei: Callionymidae) from the Mekong delta. Zootaxa 3052: 62-68.

Yoshigou H., Ohta I., Yoshino T. 2006. First record of a callionymid fish, Eleutherochir mccaddeni, from Japan. Jpn. J. Ichthyol. 52: 189-193.

http://dx.doi.org/10.11369/jji1950.53.189 